\title{
Accelerating E-Government Implementation in Indonesia Through Focuses-Based G2G Interaction: A Legal Perspective
}

\author{
Faiz Rahman, S.H., LL.M. (Cand.) \\ Faculty of Law, UNSW Australia \\ Sydney, Australia \\ faizrahman.law@gmail.com
}

\author{
Rizka Nur Faiza, S.H. \\ Constitutional Law Study Center \\ Universitas Islam Indonesia \\ Yogyakarta, Indonesia \\ rizkanurfaiza@gmail.com
}

\begin{abstract}
As the e-Government continues to be developed and implemented in Indonesia, the current condition shows that the implementation seems to be sporadic, unfocused, and has not been well integrated between the central government and regional governments, even though the Government has developed various applications and systems in regard of this implementation. This research aims to propose an idea to accelerate the implementation of e-Government through the improvement of the central government and regional governments relationship in e-Government, which is the G2G interaction, from the legal viewpoint. This research is a normative legal research, which uses the statute and conceptual approaches. The types of data that are used in this research are primary legal materials and secondary legal materials which were obtained from literature study using keyword/legislation approach, and then reviewed using the qualitative approach that eventually produces descriptive data. The results show that existing laws and regulations allowed and encouraged the technological use in the government sector. Additionally, although the e-Government development seems well progressed through many developments of e-Government applications and systems, Indonesia's EGDI rank shows a downward trend. This paper proposes focuses-based G2G interaction to accelerate the implementation of e-Government in Indonesia. There are four focuses which are determined from the General Supervision provision in Law No. 23/2014 concerning Regional Governments by taking into account various laws and regulations, definitions of e-Government, concept of central government and regional governments relationship in a unitary state context, and the existing condition of e-Government implementation, namely the regional institutions, regional finance, regional development, and public services. It is concluded that the focusesbased G2G interaction is expected to achieve a more focused, directed, and integrated e-Government implementation so that its process can be accelerated in all the regions of Indonesia.
\end{abstract}

Keywords-E-Government implementation; Focuses-Based G2G Interaction; legal perspective; supervisory approach

\section{INTRODUCTION}

The rapid development of technology has penetrated into various aspects of life, which includes social, cultural, economic, legal, and political aspects. It dramatically changes the way people communicate and interact with other people, the way companies do business, and even the way governments serve their people [1]. The discourse in applying technology in government activities has been rolled out since 2001 through
Presidential Instruction No. 6 of 2001 concerning the Development and Implementation of Telematics in Indonesia.

Two years later, the discourse was refined into National Policies and Strategies of E-Government Development through the enactment of Presidential Instruction No. 3 of 2003. Based on the consideration of the Presidential Instruction above, the National Policies and Strategies of e-Government Development aimed to improve the efficiency, effectivity, transparency, and accountability of the government administration, promote good governance, as well as enhance public services.

After 14 years since the enactment of the Presidential Instruction above, e-Government implementation in Indonesia is not showing a significant progress. It can be seen from Indonesia's rank in the UN survey on e-Government Development that indicates downward trend from 2003 to 2016. Moreover, the current implementation seems to be sporadic, not having clear focus, and has not been integrated between the central government and regional governments, as well as among regional governments. Whereas, in the context of a unitary state as Indonesia, a good relationship pattern and transfer of information between different levels of government are important for improving the quality of public services and its accountability.

This research aims to propose an idea to accelerate eGovernment implementation in Indonesia from the legal perspective. The basis of the idea is by strengthening the relationship patterns between the central government and regional governments in the e-Government context through focuses-based Government-to-Government (G2G) interaction. This research discusses a matter that should be considered fundamental, which is the focus determining of $\mathrm{G} 2 \mathrm{G}$ interaction based on the current laws and regulations perspective.

Furthermore, there are two questions arise in this research: (1) how to determine the focuses of G2G Interaction based on the existing laws and regulations? and (2) how can these focuses help the Indonesian government to accelerate the eGovernment implementation? As stated in [2] that G2G sector represents the backbone of e-Government, it is expected that improvement at this sector can help the Government to accelerate the implementation of e-Government in Indonesia holistically. 


\section{THEORETICAL BACKGROUND}

\section{A. Definitions of e-Government}

The term of electronic government (e-Government) emerged in the late 1990s. Since then, there are many experts and practitioners from different fields discussing e-Government from various aspects, including the definition for the term eGovernment itself. The following are the definitions of eGovernment presented by some experts and international organization found on several articles based on the keywords mentioned in the method part below. The authors also highlight the key aspects of each definition and the targets of eGovernment implies in each definition.

TABLE I. DEFINITIONS, KEy AsPeCtS, AND TARGETS OF E-GOVERNMENT

\begin{tabular}{|c|c|c|c|}
\hline Experts & Definition & Key aspects & Targets \\
\hline $\begin{array}{l}\text { Gartner } \\
(2000) \\
\text { See [3] }\end{array}$ & $\begin{array}{l}\text { "The continuous } \\
\text { optimization of service } \\
\text { delivery constituency } \\
\text { participation and } \\
\text { governance by } \\
\text { transforming internal and } \\
\text { external relationships } \\
\text { through technology, the } \\
\text { internet and new media." }\end{array}$ & $\begin{array}{l}\text { Optimization } \\
\text { of government } \\
\text { service } \\
\text { delivery; use of } \\
\text { technology, } \\
\text { internet, and } \\
\text { new media. }\end{array}$ & $\begin{array}{l}\text { Internal } \\
\text { (government) } \\
\text { and external } \\
\text { (public). }\end{array}$ \\
\hline $\begin{array}{l}\text { A.M. } \\
\text { Abramson } \\
\text { and E.G. } \\
\text { Means } \\
(2001) \\
\text { See [4] }\end{array}$ & $\begin{array}{l}\text { "The } \\
\text { interaction (transaction } \\
\text { and information } \\
\text { exchange) between the } \\
\text { government, the public } \\
\text { (citizens and businesses) } \\
\text { and employees." }\end{array}$ & $\begin{array}{l}\text { Electronic } \\
\text { interaction } \\
\text { between } \\
\text { government, } \\
\text { public, and } \\
\text { employees. }\end{array}$ & $\begin{array}{l}\text { Government } \\
\text { (and its } \\
\text { employees) } \\
\text { and public } \\
\text { (citizens and } \\
\text { businesses) }\end{array}$ \\
\hline $\begin{array}{l}\text { E. Fraga } \\
(2001) \\
\text { See [4] }\end{array}$ & $\begin{array}{l}\text { "The transformation of } \\
\text { public sector internal and } \\
\text { external relationships } \\
\text { through net-enabled } \\
\text { operations, IT and } \\
\text { communications, in } \\
\text { order to improve: } \\
\text { Government service } \\
\text { delivery; constituency } \\
\text { participation; society." }\end{array}$ & $\begin{array}{l}\text { Transformation } \\
\text { of public sector } \\
\text { relationships; } \\
\text { use of internet, } \\
\text { IT and } \\
\text { communication } \\
\text { to improve } \\
\text { service } \\
\text { delivery, } \\
\text { constituency } \\
\text { participation, } \\
\text { and society. }\end{array}$ & $\begin{array}{l}\text { Government } \\
\text { and public } \\
\text { (constituency, } \\
\text { society). }\end{array}$ \\
\hline $\begin{array}{l}\text { Z. } \\
\text { (2002) } \\
\text { See [3] }\end{array}$ & $\begin{array}{l}\text { "The ability to obtain } \\
\text { government services } \\
\text { through non-traditional } \\
\text { electronic means, } \\
\text { enabling access to } \\
\text { government information } \\
\text { and to completion of } \\
\text { government transaction } \\
\text { on an anywhere, anytime } \\
\text { basis a conformance with } \\
\text { equal access } \\
\text { requirement." }\end{array}$ & $\begin{array}{l}\text { Obtaining } \\
\text { government } \\
\text { services } \\
\text { through } \\
\text { electronic } \\
\text { means; } \\
\text { enabling } \\
\text { access to } \\
\text { government } \\
\text { information } \\
\text { and completion } \\
\text { of government } \\
\text { transaction. } \\
\end{array}$ & $\begin{array}{l}\text { Government } \\
\text { and public } \\
\text { (implicit). }\end{array}$ \\
\hline $\begin{array}{l}\text { Organisation } \\
\text { for } \\
\text { Economic } \\
\text { Co-operation } \\
\text { and } \\
\text { Development } \\
\text { (2003) } \\
\text { See [5] }\end{array}$ & $\begin{array}{l}\text { "The use of information } \\
\text { and communication } \\
\text { technologies, and } \\
\text { particularly the internet, } \\
\text { as a tool to achieve better } \\
\text { government." }\end{array}$ & $\begin{array}{l}\text { Use of } \\
\text { information } \\
\text { and } \\
\text { communication } \\
\text { technologies; } \\
\text { tool to achieve } \\
\text { better } \\
\text { government }\end{array}$ & Government. \\
\hline The World & "e-Government is about & Use of & Internal \\
\hline
\end{tabular}

\begin{tabular}{|c|c|c|c|}
\hline $\begin{array}{l}\text { Bank (2004) } \\
\text { See [6] }\end{array}$ & $\begin{array}{lr}\text { changing } & \text { how } \\
\text { government work, share } \\
\text { information and deliver } \\
\text { services to external and } \\
\text { internal clients using } \\
\text { information } \\
\text { communication and } \\
\text { technologies." }\end{array}$ & $\begin{array}{l}\text { information } \\
\text { and } \\
\text { communication } \\
\text { technologies to } \\
\text { change how } \\
\text { government } \\
\text { work, share } \\
\text { information } \\
\text { and deliver } \\
\text { services. }\end{array}$ & $\begin{array}{l}\text { (Government) } \\
\text { and external } \\
\text { (public). }\end{array}$ \\
\hline $\begin{array}{l}\text { European } \\
\text { Union } \\
(2004) \\
\text { See [7] }\end{array}$ & $\begin{array}{l}\text { "The use of ICT in } \\
\text { public administrations } \\
\text { combined r with } \\
\text { organizational change } \\
\text { and new skills in order to } \\
\text { improve public services } \\
\text { and democratic } \\
\text { processes." }\end{array}$ & $\begin{array}{l}\text { Use of ICT to } \\
\text { improve public } \\
\text { services and } \\
\text { democratic } \\
\text { processes. }\end{array}$ & $\begin{array}{l}\text { Government } \\
\text { and public. }\end{array}$ \\
\hline
\end{tabular}

Based on the various definitions presented in Table I above, there is a commonality in the e-Government definitions mentioned, which is the use of information and communication technologies to improve government activities. Furthermore, it can also be seen from the definitions above that the primary targets of e-Government are the government and the public. The government can be intended as government and its employees, while the public in general means citizens and businesses.

Moreover, there are two objectives that explicitly or implicitly accommodated in the definitions above, namely internal and external objectives. Internally, the goal of eGovernment implementation is to improve the effectiveness and efficiency of the government activities, while externally, it aims to improve the accessibility and delivery of government's information, accountability, and public services.

\section{B. Scopes of E-Government}

[4] explained that there are four primary targets of eGovernment implementation, which are the citizens, businesses, governments (other governments and public agencies), and employees. It is in line with the targets of eGovernment mentioned in Table 1. Therefore, based on these four targets mentioned in [4] and the targets mentioned in Table 1 above, the interactions on e-Government can be categorized into four general scopes, namely Government-toCitizen (G2C), Government-to-Business (G2B), Governmentto-Government (G2G) and Government-to-Employee (G2E). $\mathrm{G} 2 \mathrm{G}$ and $\mathrm{G} 2 \mathrm{~B}$ are related to the external objectives, whilst $\mathrm{G} 2 \mathrm{G}$ and $\mathrm{G} 2 \mathrm{E}$ are more toward the internal objectives.

\section{1) Government-to-Citizen (G2C)}

As the term implies, G2C refers to the interaction between government and citizens. In this case, the application of e-Government aims to facilitate the interaction between government and the citizens. Therefore, citizens can have more accessibility to government-and-public-related information through the online media such as website or another platform regarding several information including the general information of the regional government, information concerning laws and regulations, permit issuance requirements, local 
C. Central Government and Regional Governments Relations in a Unitary State Context

This section briefly explains the legal concept of central government and regional government relationship in a Unitary State, especially in Indonesia. It is important as it can provide a clearer picture on how the improvement of intergovernmental relationship, which is the $\mathrm{G} 2 \mathrm{G}$ interaction in e-Government context, can support the acceleration of eGovernment implementation in Indonesia.

1) Central Government and Regional Governments Relations in Indonesia

The 1945 Constitution of the Republic of Indonesia (The Constitution) stated that Indonesia is a Unitary State in the form of a Republic, which is divided into provinces, and those provinces are further divided into regencies and municipalities. [9] explained that "the essence of a unitary state is that the sovereignty is undivided, or in other words that the powers of the central government are unrestricted, for the constitution of unitary state does not admit of any other law-making body than the central one".

Although the Constitution stated that regional governments have the widest autonomy to exercise their powers to regulate and manage their government affairs, the exercise of their powers should work in accordance with the laws and regulations enacted by the Central Government according to the principles of autonomy and duty of assistance. ${ }^{1}$ Conceptually, according to the Article 4(1) of the Constitution, the President holds the governing powers. Those governing powers are elaborated into various government affairs. Furthermore, those government affairs exercised in the regions are based on the decentralization, deconcentration, and devolution principles. $^{2}$

This conceptual framework of the central government and regional governments relationship indicates the importance of this relation in the sustainability of national governmental activities. Thus, by reinforcing the relationship between the central government and regional government, hypothetically, it can also improve the implementation of e-Government.

2) Importance of Central Government and Regional Governments Relationship in e-Government Implementation

As explained above, the $\mathrm{G} 2 \mathrm{G}$ sector represents the backbone of e-Government, or can be said to be the foundation of e-Government itself. If e-Government is likened to a building, of course, it is the foundation that makes the building stand firm. If a building has a strong foundation, it will continue to stand firm despite being hit by various threats and obstacles directed to it from the

interaction) and the improvement on this sector to accelerate the e-Government implementation in Indonesia. 
outside. Therefore, it is expected that through strengthening the foundation of e-Government, which is the $\mathrm{G} 2 \mathrm{G}$ sector in this context, the implementation of eGovernment in all sectors can be holistically accelerated.

Furthermore, a good relationship between central government and regional governments is a critical component in the implementation of e-Government in Indonesia. Looking back to the framework of a unitary state, although the state is divided into numerous regions, the sovereignty of the state remained in the central government. Thus, the central government has a significant role in moving the wheels of the national government. In the context of planning and implementing national policies, the central government will heavily rely on myriads information and data owned by regional governments throughout Indonesia. It is because, these regional governments, have the better grasp of the actual condition in their respective regions. The ultimate goal is to have all national policies appropriately and optimally implemented in all parts of Indonesia.

In the technological context of e-Government implementation, there is an underlying problem regarding interoperability between the central government and regional governments caused by the diversity of eGovernment system existing in various regional governments [11]. This is a problem because in fact, in the G2G interaction, interoperability becomes one of the important factors in the context of data integration and exchange between the government agencies as well as between the central government and regional governments.

\section{METHOD}

\section{A. Research Type}

This research is a legal research. As explained in [12], legal research defined as "the process of finding the law that governs activities in human society". The method used in this research is normative legal research, which defined as "research that examines the law conceptualized as a norm or principle that applies in the society, and becomes the reference of every person's behavior" [14]. To obtain the scientific truth of legal issues examined, this research used several legal approaches. $[14,17]$ divides the legal approach into five types, namely statute, case, historical, comparative, and conceptual approach. The legal approaches used in this research are statute and conceptual approach. Statute approach is conducted by analyzing laws and regulations related to e-Government in Indonesia, while conceptual approach is carried out by reviewing experts' views concerning the concept of eGovernment as presented in the theoretical background above.

\section{B. Data Types}

The data that is mainly used in the normative legal research is secondary data. [15] divides secondary data in legal research into three types of legal materials: primary legal materials, secondary legal materials, and tertiary legal materials. Primary legal materials consist of ground norm, laws, regulations, jurisprudence, and treaty. On the other hand, secondary legal materials consist of books, journals, articles, etc., and the tertiary legal materials consist of a dictionary, index, encyclopedia, and other materials which explain primary and secondary legal materials.

This research only uses primary and secondary legal materials. The primary legal materials that are used in this research are the existing laws and regulations related to eGovernment and the relationship between the central government and regional governments. As for the secondary materials used are books, journals, articles, government and international organization's documents related to the eGovernment. No tertiary legal materials are used in this research as definitions and concepts concerning the issues discussed in this research are not obtained from dictionary or encyclopedia.

\section{Data Collection Method}

As this research is a normative legal research, the data collection method that was used is literature study. Furthermore, to obtain various information needed, the authors used keyword/legislation approach. [13] explained that it is "a way of marshalling the various aspects of information at your command and using this as a base for further research".

The specific keywords used in filtering the primary legal materials are drawn from the various definitions, key aspects, targets, objectives, scopes of e-Government, as well as concept of central government and regional governments relationship in a unitary state context as described in the previous part. Some keywords used are 'technology', 'information', 'system', 'government administration', 'relationship between central and regional government' and 'public services'. It should be noted that the laws and regulations searched are laws and regulations that are enforced nationally. Therefore, Provincial Regulation and Regency/Municipality Regulation were not sought as these regulations apply locally to the concerned region. ${ }^{3}$ Moreover, the specific keywords used in filtering secondary legal materials including 'e-Government', 'e-Government concept', 'e-Government definition', 'e-government theory', 'eGovernment in Indonesia', 'G2G interaction', and 'relationship between central and regional governments'.

\section{Data Analysis}

After the data had been obtained, it was processed and analyzed using the qualitative approach, which then produced the descriptive data [15]. It did not rule out the use of tables or graphs to support the explanation. These data were processed and analyzed by deductive reasoning method, which is the method of concluding the general problems to the specific issues [15,16]. Philipus M. Hadjon in [17] stated that in the syllogistic logic for legal reasoning, the major premise is the laws and regulations, while the minor premise is the legal facts. From these two premises, the authors then draw the conclusion and recommendation based on the relevant condition [17], in this context, e-Government in Indonesia.

For detailed hierarchy of laws and regulations, see Article 7 and 8 of Laws No. 12/2011 concerning the Formulation of Laws and Regulations. 


\section{RESULTS}

\section{A. Existing Laws and Regulations Related to E-Government in Indonesia}

Unlike the US and the Republic of Korea, Indonesia does not have a specific law regarding e-Government. However, there are some laws and regulations that its provisions are substantially related to e-Government. The following laws and regulations presented are filtered based on several keywords mentioned in the previous part and sorted by the year it was enacted.

TABLE II. LIST OF LAWS AND REGULATIONS RELATED TO E-GOVERNMENT IN INDONESIA

\begin{tabular}{|c|c|c|}
\hline No & Name of Law/Regulation & Explanation \\
\hline 1 & $\begin{array}{lccr}\text { Presidential } & \text { Instruction } & \text { No. } 3 \text { of } 2003 \\
\text { concerning } & \text { National } & \text { Policies and } \\
\text { Strategies } & \text { for } & \text { E-Government } \\
\text { Development } & & & \\
\end{array}$ & $\begin{array}{l}\text { Basis of e-Government } \\
\text { development in Indonesia. }\end{array}$ \\
\hline 2 & $\begin{array}{l}\text { Law No. } 33 \text { of } 2004 \text { concerning Fiscal } \\
\text { Balance between Central Government } \\
\text { and Regional Governments }\end{array}$ & $\begin{array}{lr}\text { Introducing } & \text { Regional } \\
\text { Finance } & \text { Information } \\
\text { System } & \\
\end{array}$ \\
\hline 3 & $\begin{array}{l}\text { Law No. } 23 \text { of } 2006 \text { concerning } \\
\text { Population Administration as amended } \\
\text { by Law No. } 24 \text { of } 2013\end{array}$ & $\begin{array}{lr}\text { Introducing } & \text { Population } \\
\text { Administration } & \text { Information } \\
\text { System } & \\
\end{array}$ \\
\hline 4 & $\begin{array}{l}\text { Law No. } 26 \text { of } 2007 \text { concerning Spatial } \\
\text { Planning }\end{array}$ & $\begin{array}{l}\text { Introducing Spatial } \\
\text { Planning Information and } \\
\text { Communication System. }\end{array}$ \\
\hline 5 & $\begin{array}{l}\text { Law No. } 11 \text { of } 2008 \text { concerning } \\
\text { Electronic Information and Transaction }\end{array}$ & $\begin{array}{l}\text { Legal basis of electronic } \\
\text { information, document, } \\
\text { certificate, system, } \\
\text { signature, transaction, and } \\
\text { contract. }\end{array}$ \\
\hline 6 & $\begin{array}{l}\text { Law No. } 14 \text { of } 2008 \text { concerning Public } \\
\text { Information Disclosure }\end{array}$ & $\begin{array}{l}\text { Regulate types of } \\
\text { Government information } \\
\text { that should be published to } \\
\text { the public. Also, require } \\
\text { Governments to develop } \\
\text { Public Information Provider } \\
\text { System }\end{array}$ \\
\hline 7 & $\begin{array}{l}\text { Law No. } 25 \text { of } 2009 \text { concerning Public } \\
\text { Services }\end{array}$ & $\begin{array}{l}\text { Introducing Public Services } \\
\text { Information System and } \\
\text { Integrated Public Services } \\
\text { System. }\end{array}$ \\
\hline 8 & $\begin{array}{llrr}\text { Law No. 32 of } 2009 \text { concerning } \\
\text { Environmental } & \text { Protection } & \text { and } \\
\text { Management } & & & \\
\end{array}$ & $\begin{array}{l}\text { Introducing Environmental } \\
\text { Information System }\end{array}$ \\
\hline 9 & Law No. 36 of 2009 concerning Health & $\begin{array}{ll}\text { Introducing } & \text { Health } \\
\text { Information System } & \\
\end{array}$ \\
\hline 10 & $\begin{array}{l}\text { Law No. } 43 \text { of } 2009 \text { concerning } \\
\text { Archive }\end{array}$ & $\begin{array}{l}\text { Introducing Archive } \\
\text { Information System }\end{array}$ \\
\hline 11 & $\begin{array}{lccc}\text { Law No. } 4 \text { of } 2011 \text { concerning } \\
\text { Geospatial Information }\end{array}$ & $\begin{array}{l}\text { Introducing } \quad \text { Geospatial } \\
\text { Information Network. }\end{array}$ \\
\hline 12 & $\begin{array}{l}\text { Minister of Administrative and } \\
\text { Bureaucratic Reform Regulation No. } 6 \\
\text { of } 2011 \text { concerning Electronic Office } \\
\text { Manuscript }\end{array}$ & $\begin{array}{l}\text { One of the basis of } \\
\text { siMAYA application }\end{array}$ \\
\hline 13 & Law No. 18 of 2012 concerning Food & $\begin{array}{ll}\text { Introducing } & \text { Food } \\
\text { Information System } & \\
\end{array}$ \\
\hline 14 & $\begin{array}{l}\text { Government Regulation No. } 82 \text { of } 2012 \\
\text { concerning Implementation of } \\
\text { Electronic System and Transaction }\end{array}$ & $\begin{array}{l}\text { Delegation of Law No. } 11 \\
\text { of } 2008 \text {. Further regulates } \\
\text { the implementation of } \\
\text { electronic system and } \\
\text { transaction. }\end{array}$ \\
\hline 15 & $\begin{array}{l}\text { Law No. } 5 \text { of } 2014 \text { concerning State } \\
\text { Civil Apparatus }\end{array}$ & $\begin{array}{lc}\text { Introducing } & \text { State } \text { Civil } \\
\text { Apparatus } & \text { Information } \\
\text { System } & \end{array}$ \\
\hline
\end{tabular}

\begin{tabular}{|c|l|l|}
\hline 16 & Law No. 6 of 2014 concerning Villages & $\begin{array}{l}\text { Introducing Village and } \\
\text { Village Area Development } \\
\text { Information System }\end{array}$ \\
\hline 17 & $\begin{array}{l}\text { Law No. 23 of 2014 concerning } \\
\text { Regional Government }\end{array}$ & $\begin{array}{l}\text { Basis of the central } \\
\text { government and regional } \\
\text { governments relationship. } \\
\text { Introducing Regional } \\
\text { Government Information } \\
\text { System and Regional } \\
\text { Development Information } \\
\text { System. }\end{array}$ \\
\hline 18 & $\begin{array}{l}\text { Presidential Regulation No. 96 of 2014 } \\
\text { concerning Indonesian Broadband Plan } \\
2014-2019\end{array}$ & $\begin{array}{l}\text { Broadband priority for e- } \\
\text { Government }\end{array}$ \\
\hline 19 & $\begin{array}{l}\text { Minister of Communication and } \\
\text { Informatics Regulation No. 21 of 2016 } \\
\text { concerning Ministry of Communication } \\
\text { and Informatics Strategic Plan 2015- } \\
2019\end{array}$ & $\begin{array}{l}\text { Database integration and e- } \\
\text { Government services in } \\
\text { Central Government and } \\
\text { Regional Governments. }\end{array}$ \\
\hline
\end{tabular}

Some observers assume that there is a need for specific Law concerning e-Government as the legal umbrella for its implementation. Although it is better to have a specific law concerning e-Government, however, there is still room for improvement in its implementation based on the existing laws and regulations listed in Table II above, as those laws and regulations allow and even encourage the technological use in the government activities. The task for the Government is to determine the focus of the implementation so that it becomes more organized and therefore can gradually improve the development of e-Government. The issue of determining the focuses and how it can help to improve the current eGovernment implementation are to be discussed in the next part.

\section{B. Current Implementation of E-Government in Indonesia}

At the early years of e-Government implementation in Indonesia, regional governments created an official website which provides information such as profiles, regional legislation, and news about the concerned region. Some of the regional governments' websites already provide the more interactive feature like suggestion, criticism, and complaints column for the public, enabling them to quickly interact with the regional government officials. Data from the Ministry of Internal Affairs in 2013 shows that almost every provinces and regencies/municipalities in Indonesia have an official website, although some of them are still offline and few of them does not even have an official website [18].

In 2011, the Ministry of Communication and Informatics developed several e-Government applications such as Integration and Data Exchange Management (MANTRA), Cyber Office Administration (siMAYA), Civil Servants Mail (PNSMail), and Private Network Security Box (PNSBox) [19]. The Central Government also has a Data Center which is used to manage and monitor government networks [20]. Furthermore, the Central Government also issued 'One Data Policy' through One Data Indonesia' website that serves to improve the interoperability and utilization of government data. However, those applications, as well as the data center and One Data Indonesia website, are only utilized by several government agencies and regional governments in Indonesia. 
Moreover, some regions, both provincial and regency/municipality, have developed regional government website portal with features like e-Budgeting, e-Procurement, e-Project, e-Health, and other similar features. Those additional features aim to ease the public services and provide public information especially those which are related to the regional government performances. The example can be seen at the City of Surabaya Government, which has supplied its website with features such as e-Health, e-Lampid (population application), e-Musrenbang (regional development planning application), and e-Budgeting. Regional Government of Banyuwangi Regency is another positive example. It releases government spending report every day through their website to promote budget transparency. It is a concrete manifestation of public information disclosure, which enables the public to assess the concerned regional government's performances.

Although it seems like there is a decent progress in the past 14 years after the enactment of Presidential Instruction No. $3 / 2003$ that includes so many developments on the regional governments' websites features and e-Government applications mentioned above, the Indonesia's global rank in the E-Government Development Index (EGDI) Survey conducted by the United Nations shows a decreasing trend. The Table III below shows Indonesia's EGDI rank from 2003 to 2016.

TABLE III. INDONESIA's E-GOVERNMENT DEVELOPMENT INDEX SURVEY RANK $(2003-2016)$

\begin{tabular}{|c|c|c|c|}
\hline Year & Global Rank & ASEAN Rank & EGDI \\
\hline 2003 & 70 & 6 & 0.422 \\
\hline 2004 & 85 & 6 & 0.3909 \\
\hline 2005 & 96 & 6 & 0.3819 \\
\hline 2008 & 106 & 7 & 0.4107 \\
\hline 2010 & 109 & 7 & 0.4026 \\
\hline 2012 & 97 & 7 & 0.4949 \\
\hline 2014 & 106 & 7 & 0.4487 \\
\hline 2016 & 116 & 6 & 0.4478 \\
\hline \multicolumn{2}{|c|}{ Source: Processed by Authors from the UN E-Government Survey 2003-2016, 2017. }
\end{tabular}

See [21-28]

The Table III above indicates a downward trend on Indonesia's EGDI global rank which fell from 70 in 2003 to 116 in 2016. While among ASEAN countries, Indonesia's rank remains stable over the last 13 -year period. The data shows that although many improvements have been made, Indonesia's e-Government development is still far behind from many countries all over the world. Despite the lack of physical infrastructure, the non-technical aspects like the relationship pattern and communication between different levels of government should be put into account by the government when developing the e-Government in Indonesia.

\section{DISCUSSION}

\section{A. Deciding Focuses on G2G Interaction: Supervisory Approach}

The discussion emphasizes the matter that must be viewed as fundamental in the implementation of e-Government in Indonesia, which is related to deciding the focuses of e-
Government implementation. The current implementation appears to be very sporadic and unstructured, regardless of various applications and systems that have been developed. It is also obvious from so many information systems introduced by different Laws as mentioned in the results part. Therefore, the outcome obtained is not maximal due to the unclear and complicated focuses on the implementation.

This research proposes a solution from the legal viewpoint in determining the focuses of e-Government implementation, especially in the context of G2G interaction. As G2G represent the backbone of e-Government, the major aspect to be considered to accelerate the implementation of e-Government thoroughly is the relationship between the central government and regional governments. Therefore, from so many laws and regulations mentioned in the Results part above, the most appropriate way to determine the focuses is using Law No. 23 of 2014 concerning Regional Governments (hereinafter Regional Government Law) which regulates the relationship pattern between the different levels of government agencies.

Furthermore, in the context of the relationship between central government and regional governments in the framework of the unitary state, regional governments essentially are accountable to the central government on the implementation of government activities in their respective regions. Thus, the authors propose the focus determination through supervisory approach as regulated in the Regional Government Law.

Supervision over the implementation of regional government is specifically regulated in Articles 377 and 378 of Regional Governments Law. Article 377 regulates the supervision of the provincial government, while Article 378 regulates the supervision of the regency/municipality government. Types of supervision in both articles are divided into general supervision and technical supervision. Based on the explanations of Articles 377 and 378, general supervision means the supervision for the distribution of Government Affairs, regional institutions, regional government apparatus, regional finance, regional development, public services in the region, regional cooperation, regional policies, and other forms of coaching in accordance with laws and regulations. On the other hand, technical supervision means supervising the implementation of the substance of Government Affairs submitted to the regions.

By taking into account the explanation above, it can be inferred that the more visible basis for the focus selection is based on the general supervision. However, not all points on the general supervision are used as the ground for the focus selection as it might fall too broad because of the phrase "and other forms of coaching ..." in the explanation of general supervision above.

Therefore, by considering various e-Government definitions, laws and regulations, central government and regional governments' relationship in a unitary state framework, and the current development of e-Government in Indonesia as described above, there are four focuses that can 
state governance as well as promoting government transparency.

interaction to accelerate the e-Government implementation, namely the regional institutions, regional finance, regional development, and public services. How these four focuses can support the acceleration of e-Government implementation in Indonesia is explained below.

\section{B. Focuses-Based G2G Interaction}

\section{1) Regional Institutions}

This point is related to the regional governance, which goal is establishing a 'good regional 'governance' and 'clean regional government'. Based on this, the central government and regional governments should focus on optimizing the government activities and alter it to become more effective and efficient. As there are applications developed by the Government such as siMAYA, the central government should be able to require all levels of regional government to use the application. This can start by enforcing it in all provincial government.

This proposition is in line with the spirit brought in the government program on bureaucratic reform and therefore can accelerate the progress. It will also indirectly trains government employees to adapt to new systems so that they can work more effectively and efficiently. The current laws and regulations are actually allowing similar development, as the siMAYA application itself is a digitalization of the Minister of Administrative and Bureaucratic Reform Regulation concerning Electronic Office Manuscript. At the higher level of regulations, this is also in accordance with the Law concerning Archive, Law concerning State Civil Apparatus, and also Law concerning Electronic Information and Transaction.

\section{2) Regional Finance}

Finance is undoubtedly one of the government's most sensitive information. It is also one of the public information that should be published to the public as stipulated in the Article 9 of Law concerning Public Information Disclosure. In the context of G2G interaction, it relates to the fiscal balance as regulated by the Law concerning Fiscal Balance between Central Government and Regional Governments, and Law concerning Management Checks and State Finance Responsibilities. As it is known, one of the bases of regional government funding is the State Budget (APBN). Therefore, any financial usage by the regional government which sourced from the state budget should be accountable to the central government.

The application such as MANTRA mentioned above (as a bridge in the data exchange between the central government and regional governments) and e-Budgeting system (for example which applied in Banyuwangi where they published daily regional financial use through their website portal) should be prioritized to be implemented in all regional governments. Thus, the $\mathrm{G} 2 \mathrm{G}$ interaction can be reinforced to support the successful implementation of

\section{3) Regional Development}

The $\mathrm{G} 2 \mathrm{G}$ interaction should be focused on this basis because regional development is the manifestation of the implementation of Government Affairs, which has been submitted to the region as an integral part of national development. ${ }^{4}$ The improvement of G2G interaction in this sector concerns on the synchronization of regional development planning and the national development planning through data integration and analysis between the central government and regional governments. For example, by using MANTRA application or e-Musrenbang system that is applied in Jakarta. Furthermore, it does not only improve the national development planning system as a whole, but also increasing public participation in the regional policy-making process. It is in accordance with the Regional Governments Law.

\section{4) Public Services}

Although this point seems to be more relevant to the G2C sector, it is actually closely tied to the G2G sector, especially on the distribution of Concurrent Government Affairs stipulated in the Regional Governments Law. There is a term in Regional Governments Law called 'Basic Services', 5 which defined as public services that are designed to fulfil the basic needs of the citizens. Therefore, the Government should prioritize the digitalization and simplification of services related to the Basic Services including education; health; and peace, public order, and public protection.

The information concerning public services, especially those are related to the Basic Services, should be integrated into a database through an application like MANTRA to enable the central government obtaining as many information as possible in regards of how public services implemented by the regional government as well as information regarding application and services that already developed or created by the various regional governments to eventually develop an application that can be implemented in all Indonesian regions. Thus, the outcome will not only be improving the data integration between different levels of governments, but also enhancing the public services. It is in accordance with some Laws such as Public Services Law and Regional Governments Law.

The four focuses above can be the foundation for eGovernment implementation as well as for the development of e-Government related applications and services. Furthermore, these four focuses can also help the government to determine priority for the infrastructure completion, which can support the acceleration of e-Government implementation. As for the current condition, it is wise to improve two main systems,

See Article 258 of the Regional Governments Law.

For the list of 'Basic Services', See Art. 12 of the Regional Government Law. 


\section{CONCLUSION}

which are MANTRA and siMAYA, to connect the sporadic implementation of e-Government in Indonesia.

First, MANTRA application, which can be utilized as a Government Service Bus (GSB) used to manage information integration and data exchange between Government agencies and Web-API that support interoperability of information system [19]. In the early stages, with the limitations of current infrastructure, the integrated data are related to the four focuses mentioned above, as these four focuses will become the basis to strengthen government productivity. The MANTRA application can be integrated with the current eGovernment applications that are implemented in some regions such as e-Budgeting, e-Musrenbang, e-Lampid, which then can be developed and applied widely throughout all Indonesian regions.

The second system is siMAYA application, which digitizes office activities such as administration, mailing, and archiving. Through this application, the government employees are enabled to adapt quicker to the rapid development of technology. Thus, it will also impact on the improvement of public services by the government employees. The various kind of information systems introduced by different laws can also be integrated using the two applications described above.

In regards of the relationship pattern between the central government and regional governments, based on the Regional Governments Law, Provincial Government has a role as an intermediary function between the central government and regency/municipality government as an autonomous region. Therefore, the provincial government can act as a temporary 'data bank' to collect various data that are relevant to the four focuses mentioned above from the regency/municipality government residing in its administrative area and the forwarding the data to the central government. Those data then are integrated and processed to become the ground for making the national policies.

Additionally, the provincial government should make a complete list of various applications or other platform of online services applied in the regency/municipality which are related to the four focuses above. Thus, the central government can accelerate the development of various eGovernment applications to have it implemented throughout all regions in Indonesia.

Furthermore, if the Central Government wishes to adopt the focuses-based $\mathrm{G} 2 \mathrm{G}$ interaction in the form of laws and regulations, by taking into account the political constellation in the People's Representative Council, the Central Government can draft a Presidential Regulation concerning this concept. It is possible because Presidential Regulation appears to be more flexible in terms of its substance, as it regulates not only substances that delegated from the Laws or Government Regulation, but also other substances to carry out the executive's governing powers. ${ }^{6}$

6 See Article 13 of Law No. 12/2011 concerning Formulation of Laws and Regulations
Finally, based on the explanation above, the focuses based G2G interaction derived from the General Supervision provision in the Regional Governments Law are expected to accelerate the e-Government implementation in Indonesia as it makes the $\mathrm{G} 2 \mathrm{G}$ interaction more focus, directed, and integrated but still in accordance with the existing laws and regulations. The improvement of $\mathrm{G} 2 \mathrm{G}$ interaction will certainly strengthen the governance basis, thus it can run more effective, efficient, accountable, and it also improves public services by the apparatus. Furthermore, it helps the Government to determine priority for the infrastructure completion and the development of applications and systems that are essential to be implemented immediately in all Indonesian regions. This concept can be adopted into the Presidential Regulation if the Central Government wishes to create a guideline that can be enforced throughout all regions in Indonesia without having to wait for the long process of typical law making in the People's Representative Council. In the end, it is expected that the development and implementation of e-Government can be accelerated, and therefore significantly improve Indonesia's e-Government rank among other countries all across the world.

\section{REFERENCES}

[1] Silcock, R. (2001). What is E-Government?. Parliamentary Affairs, 54, 88-101.

[2] Seifert, W., \& Boham, G.M. (2003, May). The Transformative Potential of E-Government in Transitional Demorcacies, Paper presented at International Conference on Public Administration in the 21st Century: Concepts, Methods, Technologies, School of Public Administration, Lomonosov Moscow State University, Moscow.

[3] Fang, Z. (2002). E-Government in Digital Era: Concept, Practice, and Development. International Journal of The Computer, The Internet and Management, 10(2), 1-22.

[4] Ndou, V. D. (2004). E-Government for Developing Countries: Opportunities and Challenges. The Electronic Journal on Information Systems in Developing Countries, 18(1), 1-24.

[5] Organisation for Economic Co-operation and Development. (2003). The e-Government Imperative. http://dx.doi.org.wwwproxy1.library.unsw.edu.au/10.1787/19901054.

[6] Bhatnagar, S., \& Deane, A. (2004). Building blocks of e-government: lessons from developing countries. PREM Notes No. 91. The World Bank. Retreived from http://documents.worldbank.org/curated/en/524191468135582219/Build ing-blocks-of-e-government-lessons-from-developing-countries.

[7] Grönlund, Å. \& Horan, T. A. (2004). Introducing e-Gov: History, Definitions, and Issues. Communications of the Association for Information System, 15, 713-729.

[8] Alshehri, M. \& Drew, S. (2010, July). E-Government Fundamentals, Paper presented at IADIS International Conference ICT, Society and Human Beings, Freiburg, Germany.

[9] Strong, C. F. (1966). Modern Political Constitution. London. Sidgwick \& Jackson Limited.

[10] Huda, N. (2009). Regional Government Law. Bandung. Penerbit Nusa Media. (Huda, N. (2009). Hukum Pemerintahan Daerah. Bandung. Penerbit Nusa Media).

[11] Widodo, A. P., Istiyanto, J. E., Wardoyo, R., \& Santoso, P. (2013). EGovernment Interoperability Framework based on a Real Time Architecture. International Journal of Computer Science Issues, 10(2), 469-477. 
[12] Cohen, M.L., \& Olson, K.C. (2002). Legal Research. St. Paul, Minn. West Publishing Company.

[13] Hutchinson, T. (2002). Researching and Writing in Law. Sydney. Lawbook Co.

[14] Muhammad, A. (2004). Law and Legal Research. Bandung. PT Citra Aditya Bakti. (Muhammad, A. (2004). Hukum dan Penelitian Hukum. Bandung. PT Citra Aditya Bakti.).

[15] Soekanto, S. (1986). Introduction to Legal Research. Jakarta. Universitas Indonesia Press. (Soekanto, S. (1986). Pengantar Penelitian Hukum. Jakarta. Universitas Indonesia Press.).

[16] Bogdan, R., \& Taylor, S.J. (1975). Introduction to Qualitative Research Methods. New York. John Willey and Sons.

[17] Marzuki, P.M. (2005). Legal Research. Jakarta. Kencana. (Marzuki, P.M. (2005) Penelitian Hukum. Jakarta. Kencana).

[18] Ministry of Internal Affairs of the Republic of Indonesia (2013, July) List of Regional Governments Website Address and Electronic Procurement Services in All Provinces, Regencies, and Municipalities in Indonesia. Retrieved from http://www.kemendagri.go.id/media/documents/2014/07/18/f/i/file. pdf. (Kementerian Dalam Negeri RI, (2013, July) Daftar Alamat Website Pemda dan LPSE Provinsi, Kabupaten, Kota Seluruh Indonesia)

[19] Ministry of Communication and Informatics of the Republic of Indonesia. (2013, October). e-Government Application. Retrieved from https://kominfo.go.id/content/detail/3319/aplikasi-egovernment/0/e_government. (Kementerian Komunikasi dan Informatika RI (2013, Oktober). Aplikasi e-Government.)

[20] Ministry of Communication and Informatics of the Republic of Indonesia. (2013, October). Data Center e-Government. Retrieved from https://kominfo.go.id/index.php/content/detail/3320/Data+Center+eGovernment/0/e_government.

[21] United Nations. (2003). UN Global E-Government Survey 2003. New York. United Nations.

[22] United Nations. (2004). United Nations Global E-Government Readiness Report 2004: Towards Access for Opportunity. New York. United Nations.

[23] United Nations. (2005). Global E-Government Readiness Report 2005: From E-Government to E-Inclusion. New York. United Nations.

[24] United Nations. (2008). UN E-Government Survey 2008: From EGovernment to Connected Governance. New York. United Nations.

[25] United Nations. (2010). United Nations E-Government Survey 2010: Leveraging e-Government at a Time of Financial and Economic Crisis. New York. United Nations.

[26] United Nations. (2012). United Nations E-Government Survey 2012: EGovernment for The People. New York. United Nations.

[27] United Nations. (2014). United Nations E-Government Survey 2014: EGovernment for The Future We Want. New York. United Nations.

[28] United Nations. (2016). United Nations E-Government Survey 2016; EGovernment in Support of Sustainable Development. New York. United Nations.

[29] Seifert, W. (2003). A Primer on E-Government: Sectors, Stages, Opportunities, and Challenges of Online Governance. Retrieved from https://fas.org/sgp/crs/RL31057.pdf. 